\title{
Die geskiedenis van Afrikaans in die Ingenieurswese en die Boukunde*
}

\author{
L.C. Eksteen \\ Departement Afrikaans, Universiteit van Pretoria
}

Die titel 'geskiedenis van Afrikaans in die Ingenieurswese en die Boukunde' hou minstens twee aspekte in: (a) Die geskiedenis van die ontwikkeling van die vakbeoefening in Afrikaans, d.w.s. ten opsigte van die mense wat die betrokke vakke daagliks as bedryf uitvoer: hoe hulle met mekaar kommunikeer, sou ons sê; d.m.v. Afrikaans, sekerlik. Hoe Afrikaans as omgangstaal, of gebruikstaal, in die bedryf sy plek kom inneem het naas Engels - om die waarheid te sê: dié plek feitlik verower het - daaroor hoef ons vandag nie meer te raas en baklei nie. Dis 'n voldonge feit. (b) Maar daar is ook 'n ander, meer verskuilde, en tog grondliggende, verskynsel. Dit is die geskiedenis van die ontwikkeling en opbou van 'n eie Afrikaanse terminologie, van 'n vaktaal wat nie net die woorde en terme en uitdrukkings van die dissiplines van die Ingenieurswese en die Boukunde sou bevat nie, maar wat ook en veral - en dus in die eerste plek - 'n beliggaamde uitdrukking moes gee aan die ervaring én die denke oor die verskynsels in dié twee wetenskaplike rigtings wat basies en wesenlik is. 'Beliggaamde uitdrukking' - daarmee bedoel ek dat die konsepte van die denke en die ervaring vasgevang word in die klank-en/of letterbeeld van wat ons 'n term noem: en met 'term' bedoel ons 'n vakwoord of -uitdrukking wat eenmalig en presies gedefinieer kan word volgens die optrede en gebruik daarvan in 'n spesifieke, omskrewe konteks, en in 'n spesifieke, afgebakende terrein van die wetenskap en tegnologie.

Wat gevolglik gebeur het in die tydperk van 'n luttele 44-45 jaar ten opsigte van die ontwikkeling van Afrikaans in die wetenskappe en tegnologiese rigtings van die Ingenieurswese en die Boukunde, was nie maar bloot 'n Afrikaanswording of 'n verafrikaansing nie. Dit sou maar iets oppervlakkigs en aangeplaks wees - want ek kan maar bloot vertaal en selfs bloot oorneem of leen uit of ontleen aan 'n ander taal, in ons geval hoofsaaklik Engels, en selftevrede agtertoe leun, my vingers genoeglik ineenstrengel en dink: dis mos verafrikaans, so word alles mettertyd Afrikaans. Nee, dit was nie so 'n oorname, so 'n lening, wat plaasgevind het op die hoogste vlak van vaktaalskepping in die afgelope geslag of wat nie: wat op hierdie vlak gebeur het, was dat Afrikaans die ter-

\footnotetext{
* Referaat gehou voor die jaarvergadering van die Afdeling Ingenieurswese van die S.A. Akademie vir Wetenskap en Kuns op Woensdag 6 Junie 1984 ter viering van die 75ste bestaansjaar van
} die Akademie. minologie van die vakke deurdink het, en dat hierdie denke uit die ervaring voortgekom het. Daar is nie bloot - en oppervlakkig - gesê: kom ons vertaal dié en dié term in Afrikaans nie; maar daar is gevra: wát is die betekenis wat ek met die en die term moet uitdruk?

Ek meen dat dit die sleutel is waarmee ons die gang van die geskiedenis van die Afrikaanse gebruik in die Ingenieurswese en Boukunde kan oopsluit: dat ons beste terme die resultate is van 'n soort worsteling met die uitdrukking van betekenis. Kom ons kyk, ter illustrasie, hoe hierdie proses van worsteling met die ekspressie van betekenis dikwels verloop het. Gelukkig het ons baie keer eerstehandse dokumentasie oor dergelike prosesse: kort geskiedenisse van die verloop vanaf aanvanklike onhelderheid en ondeursigtigheid tot uiteindelike helderheid en insig.

Daar het ' $n$ besonder insiggewende stukkie briefwisseling onder my aandag gekom oor die term $d r y$ wing vir die begrip arbeid/tyd: arbeid uitgedruk in 'n spesifieke verhouding met die tydsverloop of tempo dus. Die persoon wat sterk hiermee gemoeid was, was prof. A. Heydorn van Stellenbosch en die geskiedenis speel hom einde 1949 - begin 1950 af. Ander persone wat 'n rol speel, is dr. P.C. Schoonees, destyds van die Afrikaanse Woordeboek, ook op Stellenbosch, en die sekretariaat van die Centraal Normalisatiebureau in Nederland. Heydorn se argument het daarop neergekom dat daar nie in die Afrikaanse wetenskaplike taal en die spreektaal woorde was wat ondubbelsinnig tussen twee begrippe onderskei nie: eerstens 'n woord vir die genoemde begrip ,,arbeid per tyd"; en tweedens 'n woord vir die begrip „,massa x versnelling". Vir die laasgenoemde verskynsel word die term krag gebruik, en ons kry gebruike soos ,,die trekkrag van 'n gewig"; , die krag van 'n man se arms". Maar ook kom krag voor t.o.v. die eersge' noemde betekenis; so hoor ons byvoorbeeld van ,,'n motor se krag" en kry ons ook samestellings soos perdekrag, kragstasie, kragkop. Vergelyk ons nou Engels met Afrikaans hier, sien ons dat daar 'n onderskeid voorkom wat die betrokke konsepte betref: vir die begrip ,,arbeid/tyd" is daar die woord power; ons kry dan ook horse power, power station, ens. Vir die begrip ,massa $x$ versnelling" is die Engelse woord egter force, sodat ons onder meer kry ,,pulling force of a weight"; ,,pushing force”, ens. Ook in Duits is daar afsonderlike woorde: power heet daar Leistung; en force heet daar Kraft. Nederlands praat op sy beurt enersyds van arbeidseffek vir power en 
andersyds van kracht vir force. Heydorn wys verder daarop dat daar in die destydse Afrikaanse wetenskaplike gebruik wel terme voorgekom het soos $a r$ beidsintensiteit, arbeidsnelheid, arbeidstempo, en werkstempo. Hy beskou hierdie terme egter as onbevredigend, veral as verdere begrippe, of begripsuitbreiding, in samestellings beliggaam moet word, bv. werklike arbeidstempo, arbeidsintensiteitsentrale, arbeidsnelheidsknop, skynbare arbeidstempo.

Let nou op die probleem waarvoor die wetenskaplike werker te staan gekom het. Daar is 'n basiese onderskeiding van betekenis tussen twee natuurverskynsels blootgelê; boonop word hierdie onderskeiding na vore gebring deur die betekenisse van afsondelike woorde in twee van die vergeleke tale, nl. Engels met sy power - force-opposisie, en Duits met sy Leistung - Kraft-teenstelling. Verder vertoon die betrokke woorde in hierdie tale ' $n$ ondeelbaarheid wat hulle sonder probleme met ander woordelemente in samestellings laat verbind. Maar nou: in hierdie wetenskaplike werker se eie taal, nl. Afrikaans, is so 'n opposisie deur middel van simplekse woordgehele nie moontlik nie. Die komplekse woordgeheel wat geskep sou kon word, sou slegs trefwydte in die streng wetenskaplike toepassing op 'n bepaalde gebied, d.w.s. in 'n bepaalde dissipline, hê. Wat kennelik die wetenskaplikes en tegnoloë van veertig jaar gelede gedryf het, was 'n soeke na 'n relatief eenvoudige, ongelede woordopposisie - en dit is dus nie verbasend dat hulle onder meer die oplossing gaan soek het in die teenstelling mag $\times$ krag nie. Dit sou egter nie werk nie, want dan sou krag van sy betekenis 'force' ontneem word, en die betekenis 'force' sou aan die woord mag geheg moes word. Niemand kan 'n taal se woordvorme en hulle betekenisse - al is dit met watter krag van argumente in die wêreld - só presies en noukeurig van mekaar gaan verwyder nie.

Vandag kan ons dink dit was 'n nuttelose spel, 'n vermorsing van energie, die bespreking oor mag en krag wat op daardie llde dag van April 1950 op Stellenbosch plaasgevind het tussen lede van die Fakulteit van Ingenieurswese, die Departement Fisika, die Departement Afrikaans en die Afrikaanse Woordeboek. Tog was dit nodig.

In dié omstandighede word mettertyd die woord drywing voorgestel vir die begrip ,,arbeid/tyd”, op grond daarvan dat ' $n$ ander saaklike betekenisaspek ook na vore kom wanneer die betrokke verskynsel ontleed word. Dit is dat wanneer daar van arbeidsverrigting per tyd sprake is, gedwonge beweging van massas plaasvind, ofte wel ,,aandrywing". Hieruit volg dat begrippe soos ,,perdekrag”, ,kilowatt" e.d.m. daardeur uitgedruk kan word. Boonop kan samestellings met gemak gevorm word, waardeur ons verskynsels kan benoem soos drywingsvermoë, werksdrywing, skyndrywing, drywingskop (of dryf$k o p$ ), drywingseenheid (of dryfeenheid), ens. Wat die ingebruikstelling van die woord - eintlik nou die term - drywing in later jare betref: dis nou geskiedenis. Wat opval, is dat dit vandag naas arbeidsvermoë of net vermoe voorkom.

Dit gaan vir my in hierdie voordrag nie om die rela- tiewe voor- en nadele van bepaalde woorde en/of vakterme nie, maar oor die beginsel van woordskepping: die vasstelling van betekenis en die beliggaming daarvan in die vorme van woorde en terme.

Hier bo is daar reeds gesê dat Heydorn o.m. geargumenteer het dat die behoefte aan die betrokke woord sowel in die gewone spreektaal as in die wetenskaplike taalgebruik bestaan het. Dit bring mens weer by die besonder noue bande wat tussen hierdie twee domeine bestaan. Dit is nie so dat die taalgebruik van die wetenskaplike en die tegnoloog finaal en volkome afgesny is van dié van die volksman, die taalgebruiker puur en simpel, nie. Eerder is daar sprake van 'n groot gemeenskaplike of gedeelde domein, wat dan geleidelik oorgaan in die tallose skakerings van die wetenskaplike en tegnologiese haardgebiede: die kerne waarin onteenseglik die hartterme van elke besondere vak, ambag, tegniek, tegnologie en - as u wil - wetenskap sentreer. So is daar kennelik oor die jare heen ook oor hierdie kerne of hartterme dieselfde soort argumente gevoer en met hulle dieselfde soort probleme ondervind. Die argumente gaan oor watter betekenis uitgedruk word, en die probleme gaan oor die vind - dus dikwels ook die skepping - van geskikte terme.

Kom ons plaas wat hierbo betoog is, oor na 'n eenvoudige geval. Toe die eerste mensgemaakte satelliet op ons bewussyn ingedruis het, het ons feitlik oornag die Russiese woord spoetnik deel van die Afrikaanse ontleningskat gemaak. Maar tog: dit het nie vir ons ons betekenis van die begrip, en veral: ons ervaring daarvan, uitgedruk nie. Feitlik uit die volk - sonder die bewuste beredenering en vergaderings wat die geboorte van drywing voorafgegaan of vergesel het - het die woord kunsmaan hom op ons bewussyn afgeprent as ' $n$ uitdrukking van die betrokke betekenis in 'n Afrikaanse woord. Wat hierin opval, is dat die samestelling as woordvormingstipe se duidelike funksie na vore kom: om 'n subklas in ' $n$ groot of omvattende klas aan te dui. Die klas 'mane' word hier gereduseer tot 'n groep wat kunsmatig tot stand kom. Dit word per slot van sake heel eksplisiet in die betrokke woord uitgedruk. Let op dat dit ook in woordvormingsin die teenoorgestelde proses is as wat in die geval van drywing plaasgevind het: in daardie geval is ' $n$ ongelede woordtipe nodig gevind om ' algemene klas mee te benoem; in die geval van kunsmaan wou ons 'n spesifieke subklas binne die algemene klas onderskei.

Dat vertaling nie die begin- of die eindpunt van betekenisbenoeming kan wees nie, merk ons uit talle van die vindings wat oor die jare na vore getree het. Op die gebied van die boubedryf is daar byvoorbeeld die geval van die tipe slot wat in Engels as mortice lock bekend staan. Let op hoe daar in Afrikaans op twee maniere na die betekenis van die betrokke saak, d.w.s. die voorwerp, gekyk is. Prof. T.H. Louw vermeld in sy memorandum oor ,Verafrikaansing in die Boubedryf" dat dié tipe slot eers insteekslot genoem is, maar later toe ook gleufslot. Wat die betekenisbenoeming hier betref: in die geval van insteekslot is daar besluit om die funksie of werking van die slot te 
benoem. In die geval van gleufslot is 'n opvallende voorkomskenmerk, nl. dat daar 'n gleuf is, benoem. Nog so 'n voorbeeld van voorkomsbenoeming is kantslot, waar die Engels rimlock het. Dit sou in baie gevalle maklik wees om bloot te vertaal. So sou ons die Engelse weephole seker kon weergee met traangat; prof. Louw sê in sy memorandum egter dat die woord syfergat gebruik is: weer eens 'n benoeming volgens die betekenis - water ,traan' nie, maar ,syfer' wel.

Ons kan natuurlik soms in dié soort moeilikheid beland dat ons in die eie taal nie ' $n$ algemene klasnaam of 'n subordinaat of spesifieke subklasnaam kan vind nie. Moontlik is ons probleem groter by die algemene klasname, soos ons in die geval van $d r y$ wing gesien het, en minder groot in die geval van subklasname, soos ons dalk uit die gevalle van kunsmaan, gleufslot, dryfkop, drywingsvermoë e.d.m. kan aflei.

Nog so 'n geval van 'n algemene naam ter illustrasie: dagha. Hieruit sien ons wat ook kan gebeur: die woord waarin die betekenisbenoeming beliggaam word, is nie in die eie taal, of selfs in verwante tale, voorradig nie. Dit moet aan 'n ander, nie-verwante taal ontleen word. So kry ons 'n ontlening van die woordvorm, met 'n vae omlyning van die betekenis in die ontlenende taal, in ons geval Afrikaans. Dié betekenisomlyning is glad nie so spesifiek en besonder as in die oorsprongtaal nie. Dis vandag moontlik om te sê dat dagha in Afrikaans die algemene klas benoem: al die soorte mengsels waarmee gemessel en gepleister en gevul word, maar messelklei en pleisterklei byvoorbeeld maak twee tipes dagha uit. Hoewel die betrokke tale vreemd vir mekaar ofte wel onverwant is, staan die gebruikers van die betrokke tale sosiaal nie vreemd teenoor mekaar op die werksplek nie. Die oorgeneemde woord bevat, sosiaal gesproke, geen vreemde kleur of geur nie. Ek bring dié aspek na vore omdat daar in die vroeë vyftigerjare ook 'n ander term na vore gestoot is, om 'n aansluiting by ' $n$ verwante taal te bewerkstellig. Dit was mortel, uit Nederlands oorgeneem. Hierdie woord toon die ander sy van die prentjie; 'n aansluiting by 'n verwante taal, maar volkome vreemdheid op sosiale kontakgebied. Nie 'n wonder nie dat mortel vergete is as werkplaaswoord in Afrikaans, en op sy hoogste dalk nog 'n boekwoord is. Op dieselfde vlak as dagha kan ek 'n woord uit Engels noem wat 'n soortgelyke status het, nl. gentleman. Ons Afrikaanse woord gentleman se betekenis verskil baie sterk van dié van die Engelse woord met sy klasseverskilkonnotasies. In Afrikaans kan iemand uit die heel armste laag van die bevolking nog steeds 'n gentleman genoem word.

Hoe groot die gevaar kan wees as ons nie die betekenis van 'n begrip probeer beliggaam in die betrokke toepaslike woord of uitdrukking nie, wil ek ten slotte illustreer aan die hand van die foutiewe vertaling uit Nederlands in Engels van white rhino, waar die white sekerlik verkeerd gehoor is vir wijd (met die uitspraak [va:it] in Ndl.), d.w.s. die renoster met die bree lippe, wat - soos ons seker maar almal weet glad nie wit is nie. Toe gaan Afrikaans nie die betekenis van die betrokke saak of voorwerp benoem nie, maar - hy gaan vertaal bloot uit Engels. Nou sit ons met die eienaardige, ontersake naam wit renoster. Wat sou ons eie Afrikaanse betekenisbenoeming kon opgelewer het? Sekerlik onder meer breëliprenoster, soos mnr. V.F.C. Dreyer aantoon in sy memorandum oor ,,Afrikaanse tegniese terme” wat ek ter insae gehad het.

Dié laaste opmerking gaan net oor een ding: hoewel die sprekers van 'n taal gedurig besig is met die uitdrukking van betekenis en die oordrag daarvan, is daar maar baie slaggate op die pad. Die slaggate waarvan ons bewus is, vermy ons met minder of meer ongemak. Daardies wat ons nie van bewus is nie, of nie aan dink nie - hulle vang ons. Die ontwikkeling van die Afrikaanse vaktaal is dus nooit ' $n$ afgelope proses nie, maar gaan nimmereindigend voort. Hy leef ook nie tussen die omslae van boeke nie, maar in die daaglikse omgang en gebruik op die werkplaas, in die laboratorium, in die klaskamer - hy leef omdat hy gebruik word. Die res is boekwoorde en verstoktheid.

\section{BRONNELYS}

Dreyer, V.F.C. (1983). Afrikaanse tegniese terme. Memorandum. $4 \mathrm{pp}$.

Heydorn, A. s.j. Memorandum i.s. gebruik van die woord 'drywing' vir die begrip arbeid/tyd. Met bylaes. $20 \mathrm{pp}$.

Heydorn, A. (1951). Elektrotegniek in Afrikaans, Die Huisgenoot, 3.8.1951, 29.

Louw, T.H. (1983). Die verafrikaansing van die boubedryf. Memorandum. 3 pp. 